\title{
An inside job! Political Science's Retreat from the Public Sphere
}

Anneliese Rohrer

Columnist for the Viennese daily newspaper "Die Presse"

anneliese.rohrer@diepresse.com
The lecture hall is packed, even on the balcony. The lecturer, a woman in her late thirties or early fourties, seems a bit agitated. The PowerPoint presentation does not work. The students, clearly in the early stages of their studies, watch the effort of an assistant with a mix of indifference and amusement.

The auditorium 33 at the University of Vienna has not changed all that much in the last decades. A whiff of déjà-vu gains intensity as the lecture "Comparative analyses of politics" proceeds. It is a full frontal affair, interrupted only by the occasional questions, none of them provoking the students to any critical thoughts, all of them just testing factual knowledge. Memories of the sixties and seventies emerge. If it were not for the PowerPoint presentation, the pages of which start to disappear at an ever escalating rate as the lecture proceeds, the principals of teaching appear to be a throwback. Maybe screen shots are the technology of today - not notes.

The lecture starts out with the concept of "Rational Choice" and connects it to the Winner of the Nobel Prize in Economics of 2017. Who? None of the students know the name Richard Thaler or the concept of Behavioural Economics. "Apparently no one in here is interested in econcomics", is one of the lecturer's rather exasperating "analysis" of the student population in front of her. The other will follow later on: "As political scientists you will have to show interest in economics".

How the lecturer makes the transition from the concept of rational choice via the benefit of ignorance for political decisions ("Without ignorance there is no politics") to the political system of the United Kingdom of Great Britain is mysterious. The systematic approach to the lecture did not reveal itself in this one specific instance.

As the lecture draws to a close after a crescendo of PowerPoint pages about the parliamentary system and the electoral laws in GB, it is time to ask some students just why they chose to study political science. The answers can easily be devided into two categories: "I am interested in politics" and "They say it is not difficult." The second being clear cases of self-delusion?

Judging by the sheer number of hopefuls who sign up for first time courses each year political science can be seen as one of the most popular studies in Austria. However, as a political journalist with more than four decades of experience in national and international politics I cannot see that the popularity of political science as an academic exercise correlates in any way with the impact or influence on political debate in the public sphere. In other words: For various reasons the dedicated and forceful participation of political scientists in the public discussion of current political affairs always left a lot to be desired and still does.

Some of the reasons are peculiar Austrian. For the last fifty years political science has in general always been seen as a creation of the political "Left", heir to the so called revolt of 1968, even this revolution had been less aggressive or volatile in Austria where it also had less lasting impact than in other European countries. The recruitment process in the academic field supported that image. Political science has been regarded as the academic playground of representatives of the left with chairs especially created to accommodate them. By and large that might have been an unfair image but one that stuck nevertheless.

The second specific Austrian reason has to do with the dominance of party politics in this country. That meant - and still does - that suspicion is wide spread: What exactly is the political agenda an individual academic tries to promote with his or her research of political issues? To which of the major parties is he or she aligned to? This might always have been unfair but still is a fact to be reckoned with in a society that is heavily politicized - along party lines - like the Austrian one. 
For political scientists, the effect has been a tendency to retreat to the ivory tower and shy away from engaging in the public discourse in order to avoid being pushed into one or the other corner of the political spectrum which can be detrimental to one's own academic career.

Finally, yet another reason are the very limited professional perspectives for political scientists in Austria in the absence of a substantial number of Think Tanks like in other countries, especially the Anglosaxon ones; or of various foundations, researching political developments and drafting recommendations.

Against the backdrop of this analysis it should not come as a surprise that the former Head of the "German Association of Political Science" (Deutsche Gesellschaft für Politikwissenschaft, DGfP), Carlo Masala, voiced some fierce criticism that resonates in Austria too. In an article in the weekly "Die Zeit" in January 2017 he called the political science of today "irrelevant" and without any meaningful content. He deplored the fact that the political scientists of today shy away from analyzing politics, thus undermining their own relevance (Masala 2017).

Those are harsh words but seem to corroborate what has become obvious in recent years at least in the German speaking sphere: The theoretical and methodical approach outperforms the critical and analytical one. Substantial changes and new trends in the political development remain unaddressed. Extreme specialization, narrow subjects of research, extremely refined methods are all seen as desirable scientific characteristics. On the other hand, they spell increased alienation from the general public whose understanding of the political process they should foster.

Political science of today lacks courage, Masala argues. In his view it has become what could be called an "inside job", cultivated at innumerable conferences and in scientifically high-end journals but neither reaching nor nourishing the interests of the general public.

His point is driven home forcefully in Austria too. The chasm between political science as an academic discipline and the needs for explanations of current trends if not answers of the big questions of today seemed to have grown wider and wider in recent years as the problems have become bigger and bigger.

The silence of political scientists regarding the pressing problems of the rise of right-wing populism and/or the extreme right in the political arena has been eardeafening. One of the reasons has already be mentioned: The fear of being charged with partisanship is now more prevalent as the post-I968 generation of academics and those whose careers have been carved out in the seventies have vacated their chairs at the universities.

But take topics less loaded with party politics like the dangers modern democracies face anywhere in the world. There has not been a substantial discussion in Austria about the concepts of "controlled democracy" or "illiberal democracy" or "deficient democracy" at least not one that was brought to the attention of a wider audience. However, politicians, their consultants and most of all journalists would urgently need such a discussion based on scientific analyses and aggressively promoted by political scientists.

The list of topics which would require a scientific supervision by those whose theoretical "calling" is politics has gotten longer and longer in recent years: The politicians, the public and the media would need input from "outside" regarding changes in the electoral laws in Austria (frustratingly overcharged with party politics); the reshaping of the constitutional framework of the republic; the danger and merits of plebiscites; the obvious decline of traditional parties and the consequences for the political system as we know it - just to name a few.

And what about the analyses of the advantage of a successful integration of all the "others" the Austrian public has to come to terms with - or the dangers of failed integration at that? What was the contribution of political science to the heated public discourse on a topic that seems to concern a majority of Austrians - native or not. What is the origin and the ramification of identity politics?

Moreover, if there is or has been a prolific debate in scientific circles about the effects of the looming digitalization on the economy, the political decisions, the prospect of future employment, the cultural changes - it has been a very secret one, hidden from the eyes and ears of the general public.

Experts in the field of political science step into the lime light only in the role of political commentators of daily political events in the media - with necessary superficiality thrown into the bargain. Their number is extremely limited to maybe two or three prominent ones. The same names appear over and over again, so does their familiar input to the political business of the hour. And they are all of a certain generation. Where are the young "thinkers"? Where are their out of the box ideas, their fresh perspectives? Increasingly it seems that the pool of experts is limited to the usual suspects and everyone else is in hiding, reluctant to leave the academic cover.

Some of this can be explained by a certain ambivalent attitude that seems so characteristic of the Austrian scientific community, not in political science alone but in almost every field: On the one hand one's own research is - rightly so - considered extremely relevant and important; on the other there still is an extreme reluctance to acquire the necessary tools to communicate with the general public. The effort is considered a waste of time when the public is seen as incapable of understanding its true value. Simply rephrased: To train in the art of communicating complex scientific findings in a way the 
non-experts can understand seems to be beneath academic aspirations. Yet such training is essential.

There has been some improvement in this respect. Media training courses are being offered by the institutions themselves or externally whereas years ago they have been an unknown exercise in Austria for academics. The realization of the importance of modern communication is more widespread now than it has ever been. And yet, it is not sufficient.

Not only politicians but also the public would need the experts' view on certain developments, on possible scenarios, on future conditions that might spell danger to the established political system, even undermine it. Unbelievably important work that needs to be done by pushing it into the open arena of present-day society.

In some respect the "letter of intent", so to speak, of the Austrian Political Science Association (AuPSA) speaks volumes: None of the five activities listed concerns of the communication with the public: Research at the universities and beyond should be promoted; the interests of political scientists should be advanced; active participation in the debate about political decisions and reforms concerning the scientific community and the universities as such; internationalization of Austria's political science; and - remarkably - enhancement of the public profile of political scientists. This last point should not be mistaken for an effort to improve communication with the public.

It seems indicative in this respect that the readily available use of social media is extremely limited. A crowd sourcing effort among journalists and political consultants to find political scientists in Austria who run their own blogs rendered no results. Not a single name was produced. On Twitter only one is known to use that instrument more or less regularly. The question why exactly all the tools of the social media realm are persistently neglected by the political science community is one only that community can answer.

But to avoid any misunderstanding: Even if there should be a vibrant community whose members are in constant exchange with each other; even if there should be a number of blogs, filled by Austrian political scientists - it would be to no avail if the wider public is not confronted with them.

These are turbulent times - nationally and internationally. The contributions to the public discourse will become more important not less. Quite a lot has been written lately about the crises of political science but one statement rang especially true: Society is the ship political science should provide the compass for.

Instead of getting lost in fringe topics, trying to be on the safe side of data collecting and emphasizing methods over content, the attention should be drawn to the big questions. To back-up arguments with data would leave enough room for scientific details. But the focus should firmly be on the essential questions: What society does Austria want to live in? Which constitutional changes are necessary to stabilize the Republic in the $2 \mathrm{I}^{\text {st }}$ century? Which ballast from the post-war years is still weighting down on the Austrian political system, outdated and unnecessary in modern society? Which code of governmental practice is outdated? What are the practical requirements of the future in order to make politics more attractive for the people?

Political scientists as "intellectual hermits" as pointed out in the book "Relevance of Political Science" (Stoker et al. 2015) might never have been more uncalled for than now. At a time when too many people find political issues too complex, thus too frightening, with no relevance to their every day reality, in order to engage, intelligible guidance and explanations are important.

To put it simply: It is the task of the political scientist to make politics "sexy" again; to draw the interested audience into a lively discussion; to point out time and again that all things are political; that political decisions and practices are indeed relevant to daily life whether people choose to pay attention or not.

The best way to achieve this seems to be a concerted and renewed effort to teach students the value of critical thinking, to challenge them to ask the right questions and never give up the search for valid answers. Only political scientists who are passionate about their field of research and convinced of its relevance to society can ignite that same spark in their students.

At a time when a hitherto unknown flood of information seems to temp too many people to retreat to privacy in order to escape confusion and anxiety it is up to the experts to make sense of political developments and decisions. This of course requires an informed public, one that finds it exciting to follow events critically. In the best-case scenario information, clarity and guidance will result in the decision to engage actively in political activities - local, regional, national. This in turn would strengthen the civil society vs the political nomenclature. What greater relevance could there be?

It can only be achieved by shifting the emphasis to critical thinking, to exposing one's own opinion to critical reviews and thus to communicate the pleasures of intellectual discourses. It means leaving the academic cover, enter the Agora, alias the market place where political ideas are exchanged, and engage the public.

I See the web-page of AuPSA: http://www.oegpw.at/de/ueber-uns/ 


\section{References}

Masala, Carlo (20I7), Auf dem Rückzug, in: Zeit Campus, 23.02.2017, URL: http://www.zeit.de/2017/o7/politikwissenschaft-wissenschaftler-forschung-gesellschaftliche-relevanz (accessed: 9 January 20I8).

Stoker, Gerry/B. Guy Peters/John Pierre (Eds.) (2015b), The Relevance of Political Science, Houndmills: Palgrave Macmillan.

\section{Author}

Dr. Anneliese Rohrer

From I974 to I986 editorial journalist for the daily newspaper "Die Presse", since 1987 department manager for domestic politics. Since 200 I head for foreign affairs. 2003 Kurt Vorhofer price; 2005-2009 columnist for the daily newspaper "Kurier", since 2009 columnist for "Die Presse". Book publications: "Charakterfehler" (2005), "Ende des Gehorsams" (2OII). 